Article

\title{
Vitamin D Deficiency Is Significantly Associated with Retinopathy in Type 2 Diabetes Mellitus: A Case-Control Study
}

\author{
José M. Castillo-Otí ${ }^{1,2,3}$ (D) Ana I. Galván-Manso ${ }^{4}$, María R. Callejas-Herrero ${ }^{4}$, Luís A. Vara-González ${ }^{4}$, \\ Fernando Salas-Herrera ${ }^{4}$ and Pedro Muñoz-Cacho ${ }^{2,5, *(1)}$
}

1 Unidad Vigilancia Epidemiológica e Intervención, 39120 Liencres, Spain; josemaria.castillo@scsalud.es

2 Grupo de Investigación Salud Comunitaria IDIVAL, Primary Care Department, 39007 Santander, Spain

3 Facultad de Enfermería, Universidad de Cantabria, 39008 Santander, Spain

4 Centro de Salud La Marina, 39009 Santander, Spain; anaisabel.galvan@scsalud.es (A.I.G.-M.); rosa.callejas@scsalud.es (M.R.C.-H.); luisvara1@gmail.com (L.A.V.-G.); fresalash@hotmail.com (F.S.-H.)

5 Unidad Docente de Medicina Familiar y Comunitaria, 39011 Santander, Spain

* Correspondence: pedro.munoz@scsalud.es; Tel.: +34-699763694

check for

updates

Citation: Castillo-Otí, J.M.;

Galván-Manso, A.I.; Callejas-Herrero, M.R.; Vara-González, L.A.; Salas-Herrera, F.; Muñoz-Cacho, P. Vitamin D Deficiency Is Significantly Associated with Retinopathy in Type 2 Diabetes Mellitus: A Case-Control Study. Nutrients 2022, 14, 84. https://doi.org/10.3390/nu14010084

Academic Editor: Clive J. Petry

Received: 19 November 2021

Accepted: 20 December 2021

Published: 25 December 2021

Publisher's Note: MDPI stays neutral with regard to jurisdictional claims in published maps and institutional affiliations.

Copyright: (c) 2021 by the authors. Licensee MDPI, Basel, Switzerland. This article is an open access article distributed under the terms and conditions of the Creative Commons Attribution (CC BY) license (https:// creativecommons.org/licenses/by/ $4.0 /)$.

\begin{abstract}
Aim: Results from meta-analyses point to an association between vitamin D deficiency and the onset of diabetic retinopathy (DR). The objectives of the present study were to evaluate the association of vitamin D for the development of DR and to determine the levels of vitamin D associated with a greater risk of DR. Methods: Between November 2013 and February 2015, we performed a case-control study based on a sample of patients with diabetes in Spain. The study population comprised all patients who had at least one evaluable electroretinogram and recorded levels of 25(OH)D. We collected a series of analytical data: $25(\mathrm{OH}) \mathrm{D}, 1,25(\mathrm{OH}) 2 \mathrm{D}$, iPTH, calcium, albumin, and HbA1c. Glycemic control was evaluated on the basis of the mean HbA1c values for the period 2009-2014. A logistic regression analysis was performed to identify the variables associated with DR. Results: The final study sample comprised 385 patients, of which 30 (7.8\%) had DR. Significant differences were found between patients with and without DR for age (69.54 vs. $73.43), \mathrm{HbA} 1 \mathrm{c}(6.68 \%$ vs. $7.29 \%)$, years since diagnosis of diabetes (10.9 vs. 14.17$)$, level of $25(\mathrm{OH}) \mathrm{D}$ (20.80 vs. $15.50 \mathrm{ng} / \mathrm{mL})$, level of 1,25(OH)2D (35.0 vs. $24.5 \mathrm{pg} / \mathrm{mL})$, treatment with insulin (14.9\% vs. $56.7 \%$ ), hypertension ( $77.7 \%$ vs. $100 \%$ ), cardiovascular events ( $33.2 \%$ vs. $53.3 \%$ ), and kidney failure $(22.0 \%$ vs. $43.3 \%)$. In the multivariate analysis, the factors identified as independent risk factors for DR were treatment of diabetes $(p=0.001)$ and $25(\mathrm{OH}) \mathrm{D}(p=0.025)$. The high risk of $\mathrm{DR}$ in patients receiving insulin (OR 17.01) was also noteworthy. Conclusions: Levels of 25(OH)D and treatment of diabetes were significantly associated with DR after adjusting for other risk factors. Combined levels of $25(\mathrm{OH}) \mathrm{D}<16 \mathrm{ng} / \mathrm{mL}$ and levels of $1,25(\mathrm{OH}) 2 \mathrm{D}<29 \mathrm{pg} / \mathrm{mL}$ are the variables that best predict the risk of having DR with respect to vitamin D deficiency. The risk factor with the strongest association was the treatment of type 2 diabetes mellitus. This was particularly true for patients receiving insulin, who had a greater risk of DR than those receiving insulin analogues. However, further studies are necessary before a causal relationship can be established.
\end{abstract}

Keywords: case-control study; diabetes; diabetic retinopathy; screening program; vitamin D deficiency

\section{Introduction}

Diabetic retinopathy (DR) is responsible for $2.6 \%$ of cases of visual loss throughout the world [1]. In developed countries, it is no longer the main cause (14.4\%), having been superseded by hereditary diseases of the retina $(20.2 \%)$; this is attributed to DR screening programs and improved glycemic control [2,3].

Vitamin D has been associated with different extraskeletal effects, due to the vitamin D receptor (VDR) being present in a wide variety of cells in the body $[4,5]$ and influencing the regulation of more than 2000 genes [6]. While vitamin D deficiency has been associated with multiple diseases, not all of these associations have been verified [7]. However, several 
meta-analyses found an association between vitamin D deficiency and higher overall mortality [8], lower survival in various cancers [9], or a higher incidence of respiratory diseases [10]. In recent years, several studies examined the association between DR and vitamin $\mathrm{D}$ deficiency. The results varied mainly because of the heterogeneous nature of the studies, determined by factors such as population characteristics, vitamin D cutoff points, quality of healthcare, and adjustment for risk factors associated with DR. Two metaanalyses published in 2017 concluded that there was an association between vitamin D deficiency and onset of DR [11,12].

Nevertheless, few studies analyzed this association by controlling for risk factors associated with DR, and results are diverse [13-18]. Similarly, levels of risk of DR associated with $25(\mathrm{OH}) \mathrm{D}$ and the predictive role of $1,25(\mathrm{OH}) 2 \mathrm{D}$ have not been examined.

The objectives of the present study were to evaluate the association of vitamin $\mathrm{D}$ with $\mathrm{DR}$ and to determine the levels of vitamin D associated with a greater risk of DR.

\section{Methods}

This was a case-control study based on a sample from an analysis of prevalence of DR in patients with type 2 diabetes mellitus [19] performed between November 2013 and February 2015. The catchment area of the study was the urban area of Santander (northern Spain), which includes 10,744 patients known to have type 2 diabetes mellitus. The target population comprised patients from the study area diagnosed with type 2 diabetes mellitus according to their clinical history. Multistage cluster random sampling was performed. In the first stage, we selected one of the nine health centers from the metropolitan area (La Marina Health Center). In the second stage, we selected groups of patients from the center until the sample size was reached. Both stages were performed using simple random sampling, with probability proportional to the size of the population. Physicians updated the lists of patients with type 2 diabetes mellitus in order to avoid errors in diagnosis.

We selected all patients included in the prevalence study who had at least one evaluable retinal scan and recorded levels of $25(\mathrm{OH}) \mathrm{D}$. We defined a case as a patient with any degree of DR and a control as a patient who did not have DR. The main endpoint was $25(\mathrm{OH}) \mathrm{D}$ level. We also analyzed other covariates identified as possible risk factors for DR, namely, age, years since the diagnosis of type 2 diabetes mellitus, level of glycemic control, treatment of type 2 diabetes mellitus, control of arterial blood pressure, lipid control, obesity, smoking, 1,25(OH)2D levels, chronic kidney disease, and cardiovascular events [20].

The prevalence study identified 30 patients with DR and 355 without DR. The $25(\mathrm{OH}) \mathrm{D}$ levels were available for all patients. Therefore, for an alpha risk of $5 \%$ and a beta risk of $20 \%$ in a two-tailed test and assuming a $40 \%$ prevalence of $25(\mathrm{OH}) \mathrm{D}$ deficiency [21], the study could detect odds ratios $\geq 3$.

The patients included in the study were informed by letter and contacted via telephone by the Ophthalmology Clinic of Hospital Universitario Marqués de Valdecilla, where they underwent testing of visual acuity using Snellen optotypes with the patient's graduation and nonmydriatic retinography (Zeiss Visucam PRO NM) to obtain two photographs at $45^{\circ}$ (one centered on the macula and the other on the optic disc following the EURODIAB protocol) [22]. The photographs were taken by a single professional with experience comprising $>600$ previous scans and evaluated by a retina specialist according to the categories of the International Clinical Diabetic Retinopathy Severity Scale [23].

We performed an analytical workup in the Endocrinology Laboratory of Hospital Universitario Marqués de Valdecilla. This included 25(OH)D, 1,25(OH)2D, intact parathyroid hormone (iPTH), calcium, albumin, and HbA1c. Whole-blood $\mathrm{HbA1c}$ levels were determined using high-pressure liquid chromatography. Levels of iPTH and $25(\mathrm{OH}) \mathrm{D}$ were evaluated using a specific automated chemiluminescent immunoassay. Levels of $1,25(\mathrm{OH}) 2 \mathrm{D}$ were analyzed using a radioimmunoassay.

Patient data were obtained from the electronic clinical history of the Servicio Cántabro de Salud (Cantabrian Health Service). The clinical variables analyzed were age, sex, weight, height, body mass index (BMI), years since diagnosis of type 2 diabetes mellitus, current 
treatment of type 2 diabetes mellitus, family history of type 2 diabetes mellitus, degree of control of arterial blood pressure and dyslipidemia, cardiovascular events, chronic kidney disease, calcium/vitamin D supplements, pregnancy, and smoking.

Glycemic control was evaluated on the basis of the mean $\mathrm{HbA} 1 \mathrm{c}$ values for the period 2009-2014. Lipid control was evaluated on the basis of the mean values of total cholesterol, HDL-cholesterol (HDL-c), LDL-cholesterol (LDL-c), and triglycerides during the same period. The degree of glycemic and lipid control was analyzed following the 2015 recommendations of the American Diabetes Association [24]. High blood pressure (HBP) was evaluated by recording the mean pressures for the same period following the recommendations of the Eighth Joint National Committee (JNC8) for patients with type 2 diabetes mellitus [25]. Good control of blood pressure was defined as mean values lower than $140 / 90 \mathrm{mmHg}$ or 130/80 $\mathrm{mmHg}$ if chronic kidney disease (any stage) was recorded. Grade I hypertension was defined as 140-159 mmHg (systolic) and 90-99 mmHg (diastolic). Grade II hypertension was defined as 160-179 (systolic) and 100-109 (diastolic). Kidney failure was evaluated using the classification criteria of Kidney Disease Improving Global Outcomes [26].

The procedures were carried out after signature of the informed consent document, which was approved by the Clinical Research Ethics Committee of Cantabria (Acta 4/2014). Data were anonymized and treated confidentially according to Law 41/2002 (dated 14 November) and Law 7/2002 (dated 10 December) for Healthcare Standards of Cantabria.

The statistical analysis was performed using IBM SPSS Statistics Version 25.0 (IBM Corp, Armonk, NY, USA) and MedCalc Statistical Software Version 18.9 (MedCalc Software bvba, Ostend, Belgium; http:/ / www.medcalc.org; 2018) (accessed on 12 December 2021). The main qualitative variables were reported using percentages with $95 \%$ confidence intervals (CIs). The normality of the distribution of quantitative variables was assessed using the Kolmogorov-Smirnov test. Variables were expressed, when applicable, as the mean (SD) or median (IQR). The DeLong procedure (1988) was used to compare the area under the receiver operating characteristic (ROC) curve.

Hypothesis testing (univariate analysis) was performed using the chi-squared test or the Fisher exact test for qualitative variables. The $t$-test or Mann-Whitney test was used for quantitative variables. Statistical significance was set at $p<0.05$.

In order to identify the variables associated with DR, we performed a logistic regression analysis. The dependent variable was dichotomized as presence or absence of DR. The latter category included any grade of DR. The Youden index was used to identify levels of $25(\mathrm{OH}) \mathrm{D}$ and $1.25(\mathrm{OH}) 2 \mathrm{D}$ associated with prediction of DR. A univariate analysis was performed by estimating the OR and significance of each independent variable with the Wald statistic. Variables in the multivariate analysis were selected using the HosmerLemeshow test, as described elsewhere [27] and according to which the variables initially included in the univariate analysis were those with a level of significance of $p<0.25$. The backward elimination (conditional) method was used for automatic selection of variables in the final model. This model was compared with others with the same number of variables according to the pathophysiology and current knowledge of the subject. The ability of the different models to predict DR was compared using the area under the curve (AUC) [28]. The criterion followed was that of including one independent variable for every 10 cases of the dependent variable in the final model [29].

\section{Results}

\subsection{Characteristics of the Study Sample}

Of the 497 patients who fulfilled the inclusion criteria, 16 could not be traced, 24 refused to participate, five were eliminated owing to physical disability, 12 were eliminated because they did not attend the visit on two occasions, and 55 did not have recorded levels of 25(OH)D. The final sample comprised 385 patients (Figure 1). Table 1 shows the clinical and epidemiological characteristics of patients with and without DR. Significant differences were found for age (69.54 vs. 73.43 years), HbA1c level (6.68\% vs. 7.29\%), years 
since diagnosis of type 2 diabetes mellitus (10.9 vs. 14.17), level of 25(OH)D (20.80 vs. $15.50 \mathrm{ng} / \mathrm{mL}$ ), level of 1,25(OH)2D (35.0 vs. $24.5 \mathrm{pg} / \mathrm{mL})$, patients receiving insulin $(14.9 \%$ vs. $56.7 \%)$, hypertensive patients $(77.7 \%$ vs. $100 \%)$, cardiovascular events $(33.2 \%$ vs. $53.3 \%)$, and kidney failure (22.0\% vs. $43.3 \%)$.

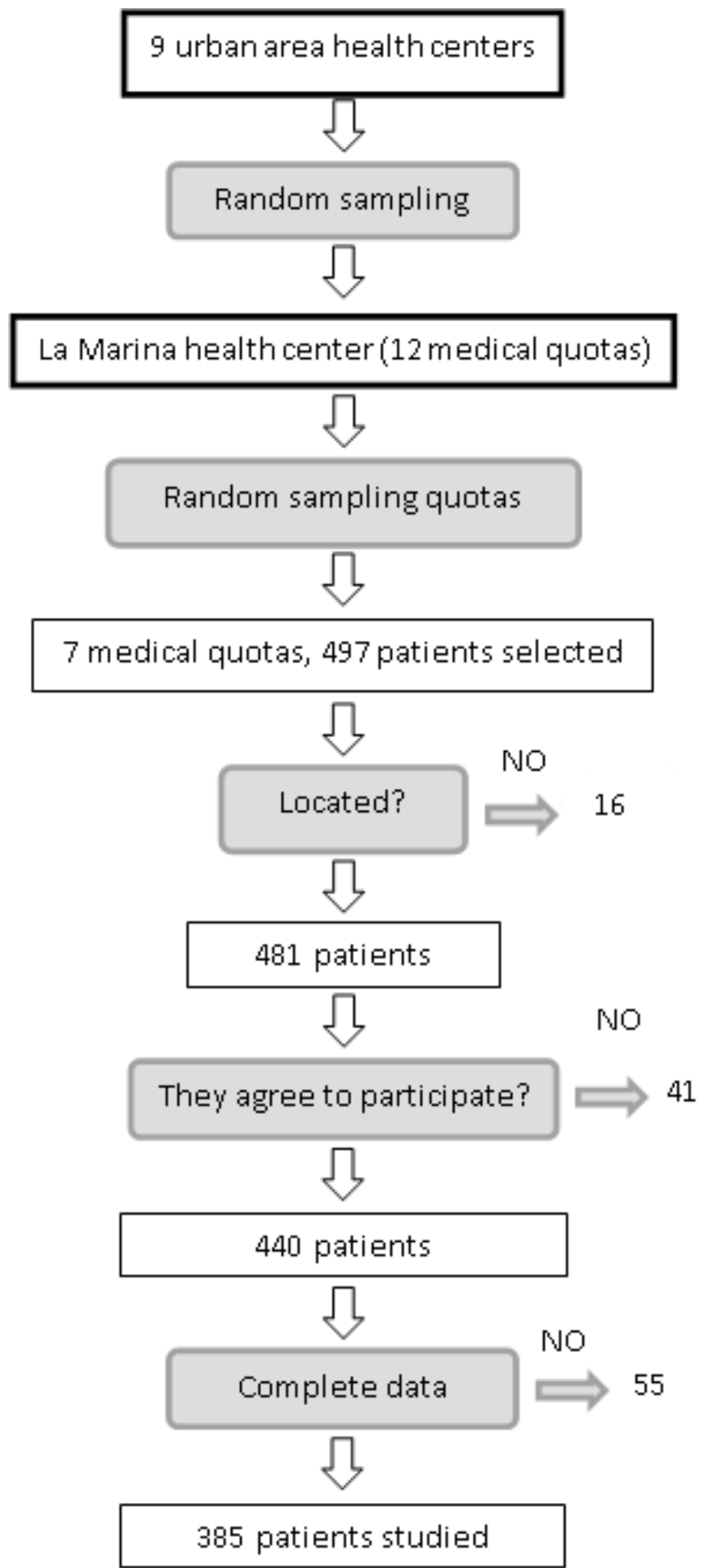

Figure 1. Selection process for patients included in the sample. 
Table 1. Clinical and epidemiological characteristics.

\begin{tabular}{|c|c|c|c|c|}
\hline Variable & Total & No DR & DR & \\
\hline & $\begin{array}{l}\text { No. (\%) or mean } \\
\text { (SD) }\end{array}$ & $\begin{array}{l}\text { No. (\%) or mean } \\
\text { (SD) }\end{array}$ & $\begin{array}{l}\text { No. (\%) or mean } \\
\text { (SD) }\end{array}$ & $p$-Value \\
\hline Age & $69.89(9.86)$ & $69.54(9.95)$ & $73.43(8.08)$ & 0.040 \\
\hline Sex & & & & 0.592 \\
\hline Men & $213(55.30)$ & $195(54.90)$ & $18(60)$ & \\
\hline Women & $172(44.70)$ & $160(45.10)$ & $12(40)$ & \\
\hline Years since diagnosis & $10.99(7.06)$ & $10.69(6.89)$ & $14.57(8.11)$ & 0.016 \\
\hline Body mass index & $29.90(4.77)$ & $29.98(4.85)$ & $28.94(3.76)$ & 0.164 \\
\hline $\mathrm{HbA} 1 c^{a}$ & $6.71(6.17,7.40)$ & $6.68(6.13,7.33)$ & $7.29(6.68,8.08)$ & 0.001 \\
\hline $25(\mathrm{OH}) \mathrm{D}^{\mathrm{a}}$ & $20(13.3,28)$ & $20.80(14,28)$ & $15.50(10.8,23.3)$ & 0.013 \\
\hline$<10 \mathrm{ng} / \mathrm{mL}$ & $28(7.30)$ & $22(6.20)$ & $6(20)$ & \\
\hline 10-31.99 & $289(75.10)$ & $267(75.20)$ & $22(73.30)$ & \\
\hline$\geq 32 \mathrm{ng} / \mathrm{mL}$ & $68(17.70)$ & $66(18.60)$ & $2(6.70)$ & \\
\hline $1,25(\overline{\mathrm{O}} \mathrm{H}) 2 \mathrm{D} \mathrm{pg} / \mathrm{mL}^{\mathrm{a}}$ & $33(20-53)$ & $35(21,54)$ & $24.50(13,38.25)$ & 0.021 \\
\hline Patients on insulin & $70(18.20)$ & $53(14.90)$ & $17(56.70)$ & $<0.001$ \\
\hline $\mathrm{HBP}$ & $306(79.50)$ & $276(77.70)$ & $30(100)$ & 0.004 \\
\hline Dyslipidemia & $255(66.20)$ & $239(67.30)$ & $16(53.30)$ & 0.120 \\
\hline Smoking & $58(16.34)$ & $54(15.20)$ & $4(13.30)$ & 0.838 \\
\hline Cardiovascular events & $134(34.80)$ & $118(33.20)$ & $16(53.30)$ & 0.027 \\
\hline Kidney failure & $91(23.60)$ & $78(22)$ & $13(43.30)$ & 0.008 \\
\hline Diabetic retinopathy & $30(7.80)$ & & & \\
\hline
\end{tabular}

DR: Diabetic Retinopathy. HBP: High blood pressure. ${ }^{a}$ Nonparametric variables. Expressed as median (interquartile range).

As for treatment of type 2 diabetes mellitus, $12.9 \%$ of patients were treated with diet, $69.0 \%$ were treated with oral antidiabetic drugs (OAD), 11.4\% were treated with $\mathrm{OAD}+$ insulin, and $6.7 \%$ were treated with insulin. The most commonly used drug was metformin $(68.2 \%)$.

Of the 385 patients for whom evaluable retinography data and $25(\mathrm{OH}) \mathrm{D}$ levels were available, 30 had DR (any grade; 7.80 , 95\% CI: 5.32, 10.94).

\subsection{Variables Associated with DR}

Mean $\mathrm{HbA1c}$ during the study period was 6.87\% (0.96) (median, $6.71 \%$ ); $67.0 \%$ of patients had a mean of $<7 \%$ and $89.4 \%$ had $\mathrm{HbA} 1 \mathrm{c}<8 \%$. HBP was recorded in $79.5 \%$ of patients, with a mean blood pressure of $140 / 76.5 \mathrm{mmHg}$ and a mean of 12.8 years since diagnosis. The prevalence of dyslipidemia was $66.2 \%$. The degree of control for each lipid factor was as follows: LDL-c $=25.5 \%$; HDL-c $=66.6 \%$; triglycerides $=64.9 \%$. Good control for all three variables was observed in only $13.7 \%$ of patients.

Values associated with the Youden index for $25(\mathrm{OH}) \mathrm{D}$ and $1,25(\mathrm{OH}) 2 \mathrm{D}$ were $\leq 16 \mathrm{ng} / \mathrm{mL}$ and $\leq 29 \mathrm{pg} / \mathrm{mL}$, respectively.

In order to analyze risk factors for DR, we performed a univariate analysis for each factor (Table 2). The results were not significant for dyslipidemia or smoking. Therefore, the variables selected for the multivariate analysis were age, years since diagnosis, BMI, glycemic control, treatment of type 2 diabetes mellitus, arterial hypertension, cardiovascular events, chronic kidney disease, 25(OH)D, and 1,25(OH)2D.

We created a composite variable-combined vitamin D-by combining levels of $25(\mathrm{OH}) \mathrm{D}$ and $1,25(\mathrm{OH}) 2 \mathrm{D}$ according to the Youden indexes and observed that patients with both metabolites below these levels had a greater risk of DR (OR 5.21, 95\% CI: 1.76, 15.42; $p=0.003$ ) (Table 3). 
Table 2. Univariate analysis of risk factors.

\begin{tabular}{|c|c|c|c|}
\hline & OR & $95 \% \mathrm{CI}$ & $p$-Value \\
\hline Female sex & 0.813 & $0.380,1.737$ & 0.592 \\
\hline Age (years) & 1.044 & $1.002,1.089$ & 0.041 \\
\hline Age at diagnosis & 1.000 & $0.964,1.036$ & 0.987 \\
\hline Years since diagnosis & 1.062 & $1.018,1.107$ & 0.005 \\
\hline Body mass index & 0.952 & $0.877,1.034$ & 0.237 \\
\hline Normal weight (reference value) & & & 0.230 \\
\hline Obesity G-1 & 1.330 & $0.426,4.152$ & 0.624 \\
\hline Obesity G-2 & 0.639 & $0.188,2.169$ & 0.473 \\
\hline \multicolumn{4}{|l|}{ Glycemic control } \\
\hline $\mathrm{HbA1c}(<7)$ (reference) & & & 0.005 \\
\hline $\operatorname{HbA1c}(7-7.9)$ & 2.911 & $1.216,6.968$ & 0.016 \\
\hline $\mathrm{HbA1c}(8-10)$ & 5.148 & $1.827,14.511$ & 0.002 \\
\hline $\operatorname{HbA1c}(>10)$ & 11.400 & $0.952,136.482$ & 0.055 \\
\hline \multicolumn{4}{|l|}{ Treatment of diabetes } \\
\hline Diet (reference value) & & & $<0.001$ \\
\hline OAD & 2.324 & $0.295,18.286$ & 0.423 \\
\hline Insulin & 21.778 & $2.542,186.566$ & 0.005 \\
\hline OAD + insulin & 12.600 & $1.526,104.035$ & 0.019 \\
\hline HBP (yes) & 4.984 & $1.175,21.130$ & 0.029 \\
\hline Cardiovascular events (yes) & 2.295 & $1.084,4.862$ & 0.030 \\
\hline No events (reference value) & & & 0.073 \\
\hline 1 event & 1.929 & $0.804,4.628$ & 0.141 \\
\hline 2 events & 3.276 & $1.173,9.150$ & 0.024 \\
\hline 3 events & - & - & - \\
\hline 4 events & 16.929 & $1.005,285.073$ & 0.050 \\
\hline \multicolumn{4}{|l|}{ Dyslipidemia } \\
\hline Good control (reference value) & & & 0.802 \\
\hline Poor control 1 factor & 0.633 & $0.245,1.635$ & 0.345 \\
\hline Poor control 2 factor & 0.688 & $0.248,1.909$ & 0.473 \\
\hline Poor control 3 factor & 0.619 & $0.185,2.068$ & 0.436 \\
\hline \multicolumn{4}{|l|}{ Kidney disease } \\
\hline Normal (reference value) & & & 0.109 \\
\hline Grade 2 (mild) & 1.849 & $0.589,5.807$ & 0.293 \\
\hline Grade 3a & 2.696 & $0.840,8.655$ & 0.096 \\
\hline Grade 3b & 4.044 & $1.218,13.429$ & 0.022 \\
\hline Grade 4 & 8.088 & $0.698,93.722$ & 0.094 \\
\hline Grade 5 & - & - & - \\
\hline Smoking & 0.892 & $0.299,2.665$ & 0.838 \\
\hline $25(\mathrm{OH}) \mathrm{D}$ & 0.947 & $0.906,0.991$ & 0.018 \\
\hline \multicolumn{4}{|l|}{ 25(OH)D Categorized } \\
\hline$>16 \mathrm{ng} / \mathrm{mL}$ (reference value) & & & 0.001 \\
\hline$\leq 16 \mathrm{ng} / \mathrm{mL}$ & 2.427 & $1.142,5.160$ & 0.021 \\
\hline \multicolumn{4}{|l|}{$1,25(\mathrm{OH}) 2 \mathrm{D}$} \\
\hline$>29 \mathrm{pg} / \mathrm{mL}$ (reference value) & & & 0.001 \\
\hline$\leq 29 \mathrm{pg} / \mathrm{mL}$ & 3.313 & $1.338,8.205$ & 0.010 \\
\hline
\end{tabular}

OAD: Oral antidiabetic drugs; HBP: High blood pressure.

Table 3. Risk according to levels of $25(\mathrm{OH}) \mathrm{D}$ combined with 1,25(OH)2D.

\begin{tabular}{cccc}
\hline Variable & $p$-Value & OR & $\mathbf{9 5 \% ~ C I ~}$ \\
\hline $25(\mathrm{OH}) \mathrm{D}>16 \mathrm{ng} / \mathrm{mL}$ and 1,25(OH)2D $>29 \mathrm{pg} / \mathrm{mL}$ & 0.011 & & \\
$25(\mathrm{OH}) \mathrm{D}>16^{\mathrm{a}}$ and $1,25(\mathrm{OH}) 2 \mathrm{D} \leq 29^{\mathrm{b}}$ & 0.882 & 1.14 & $0.21,6.04$ \\
$25(\mathrm{OH}) \mathrm{D} \leq 16^{\mathrm{a}}$ and $1,25(\mathrm{OH}) 2 \mathrm{D}>29^{\mathrm{b}}$ & 0.341 & 1.85 & $0.52,6.61$ \\
$25(\mathrm{OH}) \mathrm{D} \leq 16^{\mathrm{a}}$ and 1,25(OH)2D $\leq 29$ & 0.003 & 5.21 & $1.76,15.42$ \\
Constant & $<0.001$ & 0.04 & \\
\hline
\end{tabular}

${ }^{\mathrm{a}} \mathrm{ng} / \mathrm{mL} ;{ }^{\mathrm{b}} \mathrm{pg} / \mathrm{mL}$. 
In the initial multivariate model, with the 10 variables selected from the univariate analysis, we used the backward elimination (conditional) method to construct Model 1 , which included treatment of type 2 diabetes mellitus, degree of control of HBP, and 25(OH)D (Supplementary Table S1). The significantly associated variables were treatment of diabetes $(p=0.001)$ and $25(\mathrm{OH}) \mathrm{D}(p=0.025)$. The high risk of $\mathrm{DR}$ in patients receiving insulin (OR 17.01) was also noteworthy. The AUC for this model was $78 \%$.

We also proposed two further models. In Model 2, we used 1,25(OH)2D, and, in Model 3, we used the composite variable obtained from the level of control of $25(\mathrm{OH}) \mathrm{D}$ and 1,25(OH)2D (Table 4). The three models yielded similar AUCs, around 76-79\%, with no significant differences (Supplementary Figure S1).

Table 4. Multivariate analysis models.

\begin{tabular}{|c|c|c|c|c|}
\hline & $p$-Value & OR & $95 \%$ CI & AUC (\%) \\
\hline Model 1 & & & & 76.3 \\
\hline Treatment of diabetes (reference: Diet) & 0.000 & & & \\
\hline Oral antidiabetic drugs (OAD) & 0.436 & 2.28 & $0.29,18.11$ & \\
\hline Insulin & 0.004 & 24.93 & $2.80,221.65$ & \\
\hline $\mathrm{OAD}+$ insulin & 0.028 & 10.95 & $1.30,92.32$ & \\
\hline HBP (reference: Normal BP) & 0.167 & & & \\
\hline Stage 1 & 0.073 & 2.28 & $0.93,5.62$ & \\
\hline Stage 2 & 0.229 & 2.62 & $0.55,12.58$ & \\
\hline Levels of $25(\mathrm{OH}) \mathrm{D}(\leq 16 \mathrm{ng} / \mathrm{mL})$ & 0.027 & 2.47 & $1.11,5.52$ & \\
\hline Model 2 & & & & 78.2 \\
\hline Treatment of diabetes (reference: Diet) & 0001 & & & \\
\hline Oral antidiabetic drugs (OAD) & 0.660 & 1.60 & $0.20,13.02$ & \\
\hline Insulin & 0.035 & 11.65 & $1.18,114.64$ & \\
\hline $\mathrm{OAD}+$ insulin & 0.055 & 8.23 & $0.96,70.78$ & \\
\hline HBP (reference: Normal BP) & 0.150 & & & \\
\hline Stage 1 & 0.068 & 2.57 & $0.93,7.10$ & \\
\hline Stage 2 & 0.172 & 3.22 & $0.60,17.26$ & \\
\hline Levels of $1,25(\mathrm{OH})_{2} \mathrm{D}(<29 \mathrm{pg} / \mathrm{mL})$ & 0.038 & 2.73 & $1.06,7.07$ & \\
\hline Model 3 & & & & 79.3 \\
\hline Treatment of diabetes (reference: Diet) & 0.001 & & & \\
\hline Oral antidiabetic drugs (OAD) & 0.523 & 1.99 & $0.24,16.54$ & \\
\hline Insulin & 0.022 & 15.15 & $1.49,154.15$ & \\
\hline OAD + Insulin & 0.041 & 9.67 & $1.10,85.10$ & \\
\hline HBP (reference: Normal BP) & 0.145 & & & \\
\hline Stage 1 & 0.064 & 2.66 & $0.94,7.48$ & \\
\hline Stage 2 & 0.181 & 3.26 & $0.58,18.47$ & \\
\hline $\begin{array}{c}25(\mathrm{OH}) \mathrm{D}>16 \mathrm{ng} / \mathrm{mL} \text { and } 1,25(\mathrm{OH}) 2 \mathrm{D}> \\
29 \mathrm{pg} / \mathrm{mL}\end{array}$ & 0.046 & & & \\
\hline $25(\mathrm{OH}) \mathrm{D}>16^{\mathrm{a}}$ and $1,25(\mathrm{OH}) 2 \mathrm{D} \leq 29^{\mathrm{b}}$ & 0.507 & 1.57 & $0.41,5.99$ & \\
\hline $25(\mathrm{OH}) \mathrm{D} \leq 16^{\mathrm{a}}$ and $1,25(\mathrm{OH}) 2 \mathrm{D}>29^{\mathrm{b}}$ & 0.706 & 1.39 & $0.25,7.77$ & \\
\hline $25(\mathrm{OH}) \mathrm{D} \leq 16^{\mathrm{a}}$ and $1,25(\mathrm{OH}) 2 \mathrm{D} \leq 29^{\mathrm{b}}$ & 0.010 & 4.48 & $1.43,13.99$ & \\
\hline
\end{tabular}

${ }^{\mathrm{a}} \mathrm{ng} / \mathrm{mL} ;{ }^{\mathrm{b}} \mathrm{pg} / \mathrm{mL}$; AUC: Area under the curve; HBP: High blood pressure.

The significantly associated variables $(p<0.05)$ in the three models were treatment of diabetes and the different variables associated with vitamin $\mathrm{D}$.

In the third model, in the case of patients with low levels of both metabolites, the OR was 4.48 (95 CI\%: 1.43, 13.99) (Table 4). The AUC for this model was $79.3 \%$.

Collinearity was analyzed using a tolerance test, which yielded a negative result for all of the variables included in the multivariate models.

\section{Discussion}

Vitamin D was measured throughout the year, albeit only once per patient. No seasonal corrective factors were applied. While this could prove to be a limiting factor for 
the study results, values were distributed similarly over all four seasons. Another possible limitation of the study is that some variables such as sun exposure, diet, or socioeconomic factors were not taken into account.

The crude OR for 25(OH)D deficiency $(<20 \mathrm{ng} / \mathrm{mL})$ was 2.31 (95\% CI: 1.02, 5.22; $p=0.044$ ), which was higher than that recorded in the meta-analysis of Luo et al. [12] (OR 2.03) and Zhang et al. [11]. (OR 1.27). A similar result was obtained in a study performed in China (OR 1.93) [30]. In our meta-analysis [13,31-39], which included studies up to 2016 (Figure 2), those studies with a cutoff point of $20 \mathrm{ng} / \mathrm{mL}$ had an OR of 1.51 (95\% CI: 1.16, 1.97). Therefore, $25(\mathrm{OH}) \mathrm{D}$ deficiency was associated with DR. The OR adjusted for risk factors remained at 2.47 (95\% CI: 1.07, 5.52) in Model 1.

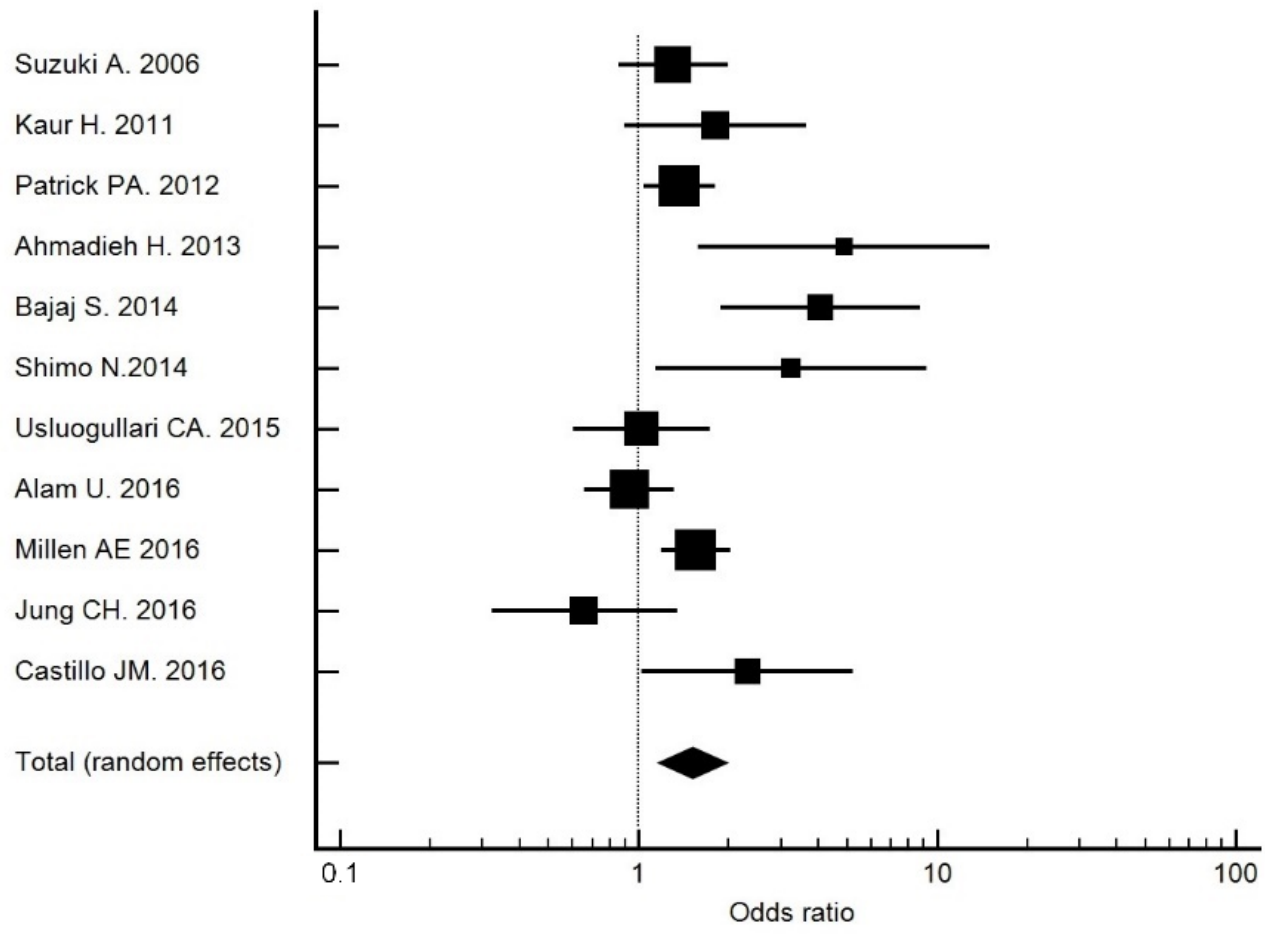

Figure 2. Forest plot of studies with a cutoff point of $20 \mathrm{ng} / \mathrm{mL}$. The total OR was 1.51 (95\% CI: $1.16,1.97)$.

It is important to highlight that, in the multivariate analysis, treatment of diabetes was the risk factor that was most strongly associated with DR, especially in patients receiving insulin. This association has been observed in other national studies with high ORs [40-43], as well as in international studies [44-47]. A cohort study [48] found that DR was more frequent during follow-up in patients who received insulin $(11.3 \%)$ than in patients who continued to take oral hypoglycemic agents (6.8\%); however, the authors did not provide an explanation for this finding. Similarly, no explanations were provided for the mechanism underlying this association, which remained unchanged after adjustment for other risk factors and, in the case of cardiovascular events, was not observed $(p=0.86)$. We applied a variable whose categories were OAD or diet (reference category), human insulin, or insulin analogue. When we compared the presence or absence of DR with this variable, we obtained a crude OR of 12.39 (95\% CI: 4.46, 34.43; $p<0.001$ ) for human insulin (Table 5). In the multivariate analysis, after controlling for the variables age, $\mathrm{HbA1c}$, years since diagnosis, hypertension, and both metabolites of vitamin D, the OR was 5.76 (95\% CI: $1.16,28.69 ; p=0.033$ ) for human insulin (Supplementary Table S2). Therefore, treatment with human insulin carries a greater risk than treatment with insulin analogues and is significantly associated with DR. Human insulin per se may cause an inflammatory or immune reaction. Excipients or retardants may also be responsible for this association. 
Other possible causes are fluctuations in blood sugar caused by the rapid action of human insulin.

Table 5. Risk of DR according to type of insulin.

\begin{tabular}{cccc}
\hline & $p$-Value & OR & 95\% CI \\
\hline Diet or OAD & $<0.001$ & & \\
(reference) & $<0.001$ & 5.65 & $2.26,14.12$ \\
Insulin analogues & $<0.001$ & 12.39 & $4.46,34.43$ \\
Human insulin & &
\end{tabular}

OAD: Oral antidiabetic drugs.

While $16 \mathrm{ng} / \mathrm{mL}$ is the cutoff point for $25(\mathrm{OH}) \mathrm{D}$ that best predicts the risk of DR (OR 2.43), patients with levels $<20 \mathrm{ng} / \mathrm{mL}$ had a similar risk (OR 2.29), as shown in Supplementary Table S3. The behavior of the combined variable (vitamin D metabolites) was particularly interesting, since, when both metabolites were below their Youden index, the risk of DR multiplied (OR 5.21, 95\% CI: 1.76, 15.42; $p=0.003$ ). This effect was maintained, as can be seen in Model 3 of the multivariate analysis. Therefore, we can consider it a good tool for predicting the onset of DR. This effect may be due to the fact that low levels of both metabolites were observed in patients with severe vitamin $\mathrm{D}$ deficiency maintained over time. Therefore, we believe that the measurement of both metabolites is justified, since $1,25(\mathrm{OH}) 2 \mathrm{D}$ is useful for identifying those patients who are at the highest risk.

\section{Conclusions}

In conclusion, the levels of $25(\mathrm{OH}) \mathrm{D}$ and treatment of diabetes are significantly associated with DR after adjusting for other risk factors.

Combined levels of $25(\mathrm{OH}) \mathrm{D}<16 \mathrm{ng} / \mathrm{mL}$ and $1,25(\mathrm{OH}) 2 \mathrm{D}<29 \mathrm{pg} / \mathrm{mL}$ are the best predictors of the risk of having DR, with respect to vitamin D deficiency.

While not the objective of our study, the risk variable with the strongest association was treatment of type 2 diabetes mellitus. This was particularly true for patients receiving insulin, who had a greater risk of DR than those receiving insulin analogues. However, further studies are necessary before a causal relationship can be established.

Supplementary Materials: The following supporting information can be downloaded at: https: / / www.mdpi.com/article/10.3390/nu14010084/s1, Figure S1: Area under de curve of the 3 models. Pairwise comparison of ROC curves: DeLong test; Table S1: Initial model, Model 0, and steps in conditional backward selection variables; Table S2: Effect of treatment with insulin controlled for the variables age, years since onset, vitamin D, glycemic control, and control of HBP.

Author Contributions: Conceptualization, J.M.C.-O. and P.M.-C.; methodology, J.M.C.-O. and P.M.-C.; software, P.M.-C.; validation, L.A.V.-G., F.S.-H., A.I.G.-M. and M.R.C.-H.; formal analysis, P.M.-C.; investigation, J.M.C.-O.; resources, P.M.-C.; data curation, J.M.C.-O.; writing-original draft preparation, J.M.C.-O. and P.M.-C.; writing-review and editing, J.M.C.-O. and P.M.-C.; visualization, J.M.C.-O.; supervision, J.M.C.-O.; project administration, P.M.-C.; funding acquisition, J.M.C.-O. and P.M.-C.; All authors have read and agreed to the published version of the manuscript.

Funding: This research was partially supported by a grant fron Instituto de Investigación Valdecilla (IDIVAL) \#PRINVAL 17/02.

Informed Consent Statement: Informed consent was obtained from all subjects involved in the study.

Data Availability Statement: The data presented in this study are available on request from the corresponding author.

Conflicts of Interest: The authors declare no conflict of interest.

Financial Support: The authors thank Novartis Farmacéutica S.A. for their impartial collaboration in this study by providing the Zeiss VISUCAM PRO NM device and Fundación redGDPS for covering the costs of the vitamin D reagents. The sponsors or funding organizations had no role in the design or conduct of this research. 


\section{References}

1. Bourne, R.R.; Stevens, G.A.; White, R.A.; Smith, J.L.; Flaxman, S.R.; Price, H.; Jonas, J.B.; Keeffe, J.; Leasher, J.; Naidoo, K.; et al. Causes of visión loss worldwide. Syst. Anal. 2013, 1, e339-e349.

2. Liew, G.; Michaelides, M.; Bunce, C. A comparison of the causes of blindness certifications in England and Wales in working age adults (16-64 years), 1999-2000 with 2009-2010. BMJ Open 2014, 4, e004015. [CrossRef] [PubMed]

3. Quartilho, A.; Simkiss, P.; Zekite, A.; Xing, W.; Wormald, R.; Bunce, C. Leading causes of certifiable visual loss in England and Wales during the year ending 31 March 2013. Eye 2016, 30, 602-607. [CrossRef] [PubMed]

4. Wacker, M.; Holick, M.F. Vitamin D-Effects on skeletal and extraskeletal health and the need for supplementation. Nutrients 2013, 5, 111-148. [CrossRef] [PubMed]

5. Haussler, M.R.; Livingston, S.; Sabir, Z.L.; Haussler, C.A.; Jurutka, P.W. Vitamin D Receptor Mediates a Myriad of Biological Actions Dependent on Its 1,25-Dihydroxyvitamin D Ligand: Distinct Regulatory Themes Revealed by Induction of Klotho and Fibroblast Growth Factor-23. JBMR Plus 2020, 5, e10432. [CrossRef] [PubMed]

6. Holick, M.F. Vitamin D deficiency. N. Engl. J. Med. 2007, 357, 266-281. [CrossRef]

7. Scragg, R.; Sluyter, J.D. Is There Proof of Extraskeletal Benefits From Vitamin D Supplementation From Recent Mega Trials of Vitamin D? JBMR Plus 2021, 5, e10459. [CrossRef] [PubMed]

8. Schöttker, B.; Ball, D.; Gellert, C.; Brenner, H. Serum 25-hydroxyvitamin D levels and overall mortality. A systematic review and meta-analysis of prospective cohort studies. Ageing Res. Rev. 2013, 12, 708-718. [CrossRef] [PubMed]

9. Keum, N.; Lee, D.H.; Greenwood, D.C.; Manson, J.E.; Giovannucci, E. Vitamin D supplementation and total cancer incidence and mortality: A meta-analysis of randomized controlled trials. Ann. Oncol. 2019, 30, 733-743. [CrossRef] [PubMed]

10. Jolliffe, D.A.; Camargo, C.A., Jr.; Sluyter, J.D.; Aglipay, M.; Aloia, J.F.; Ganmaa, D.; Bergman, P.; Bischoff-Ferrari, H.A.; Borzutzky, A.; Damsgaard, C.T.; et al. Vitamin D supplementation to prevent acute respiratory infections: A systematic review and meta-analysis of aggregate data from randomised controlled trials. Lancet Diabetes Endocrinol. 2021, 9, 276-292. [CrossRef]

11. Zhang, J.; Upala, S.; Sanguankeo, A. Relationship between vitamin D deficiency and diabetic retinopathy: A meta-analysis. Can. J. Ophthalmol. 2017, 52, 219-224. [CrossRef] [PubMed]

12. Luo, B.A.; Gao, F.; Qin, L.L. The Association between Vitamin D Deficiency and Diabetic Retinopathy in Type 2 Diabetes: A Meta-Analysis of Observational Studies. Nutrients 2017, 9, 307. [CrossRef] [PubMed]

13. Alam, U.; Amjad, Y.; Chan, A.W.; Asghar, O.; Petropoulos, I.N.; Malik, R.A. Vitamin D Deficiency Is Not Associated with Diabetic Retinopathy or Maculopathy. J. Diabetes Res. 2016, 2016, 6156217. [CrossRef]

14. Alcubierre, N.; Valls, J.; Rubinat, E.; Cao, G.; Esquerda, A.; Traveset, A.; Granado-Casas, M.; Jurjo, C.; Mauricio, D. Vitamin D Deficiency Is Associated with the Presence and Severity of Diabetic Retinopathy in Type 2 Diabetes Mellitus. J. Diabetes Res. 2015, 2015, 374178. [CrossRef]

15. Herrmann, M.; Sullivan, D.R.; Veillard, A.-S.; McCorquodale, T.; Straub, I.R.; Scott, R.; Laakso, M.; Topliss, D.; Jenkins, A.; Blankenberg, S.; et al. Serum 25-hydroxyvitamin D: A predictor of macrovascular and microvascular complications in patients with type 2 diabetes. Diabetes Care 2015, 38, 521-528. [CrossRef]

16. Zoppini, G.; Galletti, A.; Targher, G.; Brangani, C.; Pichiri, I.; Trombetta, M.; Negri, C.; De Santi, F.; Stoico, V.; Cacciatori, V.; et al. Lower levels of 25-hydroxyvitamin D3 are associated with a higher prevalence of microvascular complications in patients with type 2 diabetes. BMJ Open Diabetes Res. Care 2015, 3, e000058. [CrossRef] [PubMed]

17. Engelen, L.; Schalkwijk, C.G.; Eussen, S.J.P.M.; Scheijen, J.L.J.M.; Soedamah-Muthu, S.S.; Chaturvedi, N.; Fuller, J.H.; Stehouwer, C.D.A. Low 25-hydroxyvitamin D2 and 25-hydroxyvitamin D3 levels are independently associated with macroalbuminuria, but not with retinopathy and macrovascular disease in type 1 diabetes: The EURODIAB prospective complications study. Cardiovasc. Diabetol. 2015, 14, 67. [CrossRef] [PubMed]

18. Jee, D.; Han, K.D.; Kim, E.C. Inverse Association between High Blood 25-Hydroxyvitamin D Levels and Diabetic Retinopathy in a Representative Korean Population. PLoS ONE. 2014, 9, e115199. [CrossRef]

19. Castillo Otí, J.M. Prevalencia y Factores de Riesgo Asociados a la Retinopatía Diabética en Cantabria. Ph.D. Thesis, Universidad de Cantabria, Santander, Spain, 2016.

20. Yau, J.W.Y.; Rogers, S.L.; Kawasaki, R.; Lamoureux, E.L.; Kowalski, J.W.; Bek, T.; Chen, S.-J.; Dekker, J.M.; Fletcher, A.; Grauslund, J.; et al. Meta-Analysis for Eye Disease (META-EYE) Study Group. Global prevalence and major risk factors of diabetic retinopathy. Diabetes Care 2012, 35, 556-564. [CrossRef]

21. Navarro Valverde, C.; Quesada Gómez, J.M. Vitamin D Deficiency in Spain. Reality or Myth? Rev. Osteoporos. Metab. Min. 2014, 6, 5-10. Available online: http:/ / scielo.isciii.es/scielo.php?script=sci_arttext\&pid=S1889-836X2014000500002\&Ing=es (accessed on 26 November 2021). [CrossRef]

22. Aldington, S.J.; Kohner, E.M.; Meuer, S.; Klein, R.; Sjolie, A.K. Methodology for retinal photography and assessment of diabetic retinopathy: The EURODIAB IDDM complications study. Diabetología 1995, 38, 437-444. [CrossRef] [PubMed]

23. Wilkinson, C.P.; Ferris, F.L.; Klein, R.E.; Lee, P.P.; Agardh, C.D.; Davis, M.; Dills, D.; Kampik, A.; Pararajasegaram, R.; Verdaguer, J.T. Proposed International Clinical Diabetic Retinopathy and Diabetic Macular Edema Disease Severity Scales. Ophthalmology 2003, 110, 1677-1682. [CrossRef]

24. American Diabetes Association. Standards of medical care in diabetes-2015. Diabetes Care 2015, 38, 49-57. [CrossRef] 
25. James, P.A.; Oparil, S.; Carter, B.L.; Cushman, W.C.; Dennison-Himmelfarb, C.; Handler, J.; Lackland, D.T.; Lefevre, M.L.; MacKenzie, T.D.; Ogedegbe, O.; et al. Evidence based guideline for the management of high blood pressure in adults: Report from the panel members appointed to the Eighth Joint National Committee (JNC 8). JAMA 2014, 311, 507-520. [CrossRef]

26. KDIGO 2012 clinical practice guideline for the evaluation and management of chronic kidney disease. Kidney Int. Suppl. 2013, 3, $5-14$.

27. Hosmer, D.W.; Lemeshow, S. Applied logistic regression. In Model-Building Strategies and Methods for Logistic Regression, 3rd ed.; Whiley: Hoboken, NJ, USA, 2013; Chapter 4, pp. 89-151.

28. Hilbe, J.M. Logistic regression models. In Analysis of Model Fit; Chapman \& Hall/CRC Press: Boca Raton, FL, USA, 2009; Chapter 7, pp. 243-296.

29. Vittinghoff, E.; McCulloch, C.E. Relaxing the rule of ten events per variable in logistic and Cos regression. Am. J. Epidemiol. 2007, 165, 710-718. [CrossRef]

30. He, R.; Shen, J.; Liu, F.; Zeng, H.; Li, L.; Yu, H.; Lu, H.; Wu, Q.; Jia, W. Vitamin D deficiency increases the risk of retinopathy in Chinese patients with type 2 diabetes. Diabet. Med. 2014, 31, 1657-1664. [CrossRef] [PubMed]

31. Suzuki, A.; Kotake, M.; Ono, Y.; Kato, T.; Oda, N.; Hayakawa, N.; Hashimoto, S.; Itoh, M. Hypovitaminosis D in type 2 diabetes mellitus: Association with microvascular complications and type of treatment. Endocr. J. 2006, 53, 503-510. [CrossRef]

32. Kaur, H.; Donaghue, K.C.; Chan, A.K.; Benitez-Aguirre, P.; Hing, S.; Lloyd, M.; Cusumano, J.; Pryke, A.; Craig, M.E. Vitamin D deficiency is associated with retinopathy in children and adolescents with type 1 diabetes. Diabetes Care 2011, 34, 1400-1402. [CrossRef] [PubMed]

33. Patrick, P.A.; Visintainer, P.F.; Shi, Q.; Weiss, I.A.; Brand, D.A. Vitamin D and retinopathy in adults with diabetes mellitus. Arch Ophthalmol. 2012, 130, 756-760. [CrossRef]

34. Ahmadieh, H.; Azar, S.T.; Lakkis, N.; Arabi, A. Hypovitaminosis D in Patients with Type 2 Diabetes Mellitus: A Relation to Disease Control and Complications. ISRN Endocrinol. 2013, 2013, 641098. [CrossRef] [PubMed]

35. Bajaj, S.; Singh, R.P.; Dwivedi, N.C.; Singh, K.; Gupta, A.; Mathur, M. Vitamin D levels and microvascular complications in type 2 diabetes. Indian J. Endocrinol. Metab. 2014, 18, 537-541. [CrossRef]

36. Shimo, N.; Yasuda, T.; Kaneto, H.; Katakami, N.; Kuroda, A.; Sakamoto, F.; Takahara, M.; Irie, Y.; Horikawa, K.; Miyashita, K.; et al. Vitamin D deficiency is significantly associated with retinopathy in young Japanese type 1 diabetic patients. Diabetes Res. Clin. Pract. 2014, 106, 41-43. [CrossRef] [PubMed]

37. Usluogullari, C.A.; Balkan, F.; Caner, S.; Ucler, R.; Kaya, C.; Ersoy, R.; Cakir, B. The relationship between microvascular complications and vitamin D deficiency in type 2 diabetes mellitus. BMC Endocr. Disord. 2015, 15, 33. [CrossRef] [PubMed]

38. Millen, A.E.; Sahli, M.W.; Nie, J.; LaMonte, M.J.; Lutsey, P.L.; Klein, B.E.K.; Mares, J.A.; Meyers, K.J.; Andrews, C.A.; Klein, R. Adequate vitamin D status is associated with the reduced odds of prevalent diabetic retinopathy in African Americans and Caucasians. Cardiovasc. Diabetol. 2016, 15, 128. [CrossRef] [PubMed]

39. Jung, C.H.; Kim, K.J.; Kim, B.Y.; Kim, C.H.; Kang, S.K.; Mok, J.O. Relationship between vitamin D status and vascular complications in patients with type 2 diabetes mellitus. Nutr. Res. 2016, 36, 117-124. [CrossRef] [PubMed]

40. Rodriguez-Poncelas, A.; Miravet-Jiménez, S.; Casellas, A.; La Puente, J.F.B.-D.; Franch-Nadal, J.; López-Simarro, F.; Mata-Cases, M.; Mundet-Tudurí, X. Prevalence of diabetic retinopathy in individuals with type 2 diabetes who had recorded diabetic retinopathy from retinal photographs in Catalonia (Spain). Br. J. Ophthalmol. 2015, 99, 1628-1633. [CrossRef] [PubMed]

41. Romero-Aroca, P.; de la Riva-Fernández, S.; Valls-Mateu, A.; Sagarra-Alamo, R.; Moreno-Ribas, A.; Soler, N. Changes observed in diabetic retinopathy: Eight-year follow-up of a Spanish population. Br. J. Ophthalmol. 2016, 100, 1366-1371. [CrossRef] [PubMed]

42. Romero-Aroca, P.; Fernández-Alart, J.; Baget-Bernaldiz, M.; Méndez-Marín, I.; Salvat-Serra, M. Diabetic Retinopathy Epidemiology in Type II Diabetic Patients. Effec of the Changes in the Diagnostic Criteria and the Stricter Control of the Diabetes between 1993 and 2005 on the Incidence of Diabetic Retinopathy. Arch. Soc. Esp. Oftalmol. 2007, 82, 209-218.

43. Santos-Bueso, E.; Fernández-Pérez, C.; Macarro, A.; Fernández-Vigo, J. Prevalence of diabetic retinopathy in the city of Badajoz 2002 (Extremadura project to prevent blindness). Arch. Soc. Esp. Oftalmol. 2007, 82, 153-158. [PubMed]

44. Thomas, R.L.; Dunstan, F.D.; Luzio, S.D.; Chowdhury, S.R.; North, R.V.; Hale, S.L.; Gibbins, R.L.; Owens, D.R. Prevalence of diabetic retinopathy within a national diabetic retinopathy screening service. Br. J. Ophthalmol. 2015, 99, 648. [CrossRef]

45. Wong, T.Y.; Klein, R.; Islam, F.M.A.; Cotch, M.F.; Folsom, A.R.; Klein, B.E.; Sharrett, A.R.; Shea, S. Diabetic retinopathy in a multi-ethnic cohort in the United States. Am. J. Ophthalmol. 2006, 141, 446-455. [CrossRef] [PubMed]

46. Tapp, R.J.; Shaw, J.E.; Harper, C.A.; de Courten, M.P.; Balkau, B.; McCarty, D.J.; Taylor, H.R.; Welborn, T.A.; Zimmet, P.Z. The prevalence of and factors associated with diabetic retinopathy in the Australian population. Diabetes Care 2003, 26, 1731-1737. [CrossRef] [PubMed]

47. Broadbent, D.M.; Scott, J.A.; Vora, J.P.; Harding, S.P. Prevalence of diabetic eye disease in an inner city population: The Liverpool Diabetic Eye Study. Eye 1999, 13, 160-165. [CrossRef] [PubMed]

48. Mast, R.; Jansen, A.P.D.; Walraven, I.; Rauh, S.P.; Heijden, A.A.W.A.V.D.; Heine, R.J.; Elders, P.J.M.; Dekker, J.M.; Nijpels, G.; Hugtenburg, J.G. Time to insulin initiation and longterm effects of initiating insulin in people with type 2 diabetes mellitus: The Hoorn Diabetes Care.System Cohort Study. Eur. J. Endocrinol. 2016, 174, 563-571. [CrossRef] 